\title{
Air Pollution and Respiratory Permeability in Obstructive Sleep Apnea - A Review
}

Aerosol and Air Quality Research

\section{OPEN ACCESS}

Received: July 2, 2020

Revised: October 1, 2020

Accepted: November 11, 2020

${ }^{*}$ Corresponding Author:

r92841005@ntu.edu.tw

\section{Publisher:}

Taiwan Association for Aerosol Research

ISSN: $1680-8584$ print

ISSN: 2071-1409 online

(c) Copyright: The Author(s).

This is an open access article distributed under the terms of the Creative Commons Attribution License (CC BY 4.0), which permits unrestricted use, distribution, and reproduction in any medium, provided the original author and source are cited.

\section{Nguyen Thanh Tung ${ }^{1,2}$, Hoang Ba Dung ${ }^{2}$, Tran Phan Chung Thuy ${ }^{3}$, Huynh Nguyen Xuan Thao ${ }^{4}$, Hsiao-Chi Chuang ${ }^{5,6,7^{*}}$}

${ }^{1}$ International Ph.D. Program in Medicine, College of Medicine, Taipei Medical University, Taipei, Taiwan

${ }^{2}$ Otorhinolaryngology Department, Cho Ray Hospital, Ho Chi Minh City, Vietnam

${ }^{3}$ Otorhinolaryngology Department, Faculty of Medicine, Vietnam National University Ho Chi Minh City, Ho Chi Minh City, Vietnam

${ }^{4} \mathrm{Ho}$ Chi Minh City University of Medicine and Pharmacy, Ho Chi Minh City, Vietnam

${ }^{5}$ School of Respiratory Therapy, College of Medicine, Taipei Medical University, Taipei, Taiwan

${ }^{6}$ Division of Pulmonary Medicine, Department of Internal Medicine, Shuang Ho Hospital, Taipei Medical University, New Taipei City, Taiwan

${ }^{7}$ Cell Physiology and Molecular Image Research Center, Wan Fang Hospital, Taipei Medical University, Taipei, Taiwan

\section{ABSTRACT}

Obstructive sleep apnea (OSA) is a common disorder characterized by recurrent episodes of nocturnal upper airway obstruction during sleep, which can seriously affect sleep quality and cause sleepiness during the daytime. Known risk factors for OSA are numerous, including obesity, age, gender, craniofacial anatomy, smoking, alcohol consumption, and genetic inheritance. Recently, air pollution was linked to an increased risk of OSA severity. Alterations in permeability are considered to be an important factor in the development of OSA; however, the role of air pollution remains unclear. This review article explored the role of air pollution and airway permeability in the pathogenesis of OSA.

Keywords: Apnea Hypopnea Index, Nocturnal fluid shift, Obstructive sleep apnea, Particulate matter, Permeability

\section{INTRODUCTION}

Economic burdens related to obstructive sleep apnea (OSA) account for billions of US dollars annually (AlGhanim et al., 2008). Costs associated with OSA mostly arise from OSA diagnoses, treatments, and comorbidities (Kapur, 2010). Estimated costs for undiagnosed OSA range \$34 billion to $\$ 69$ billion annually (Knauert et al., 2015). People with sleep disorders also work less efficiently than those without sleep difficulties (Sherman, 2013). In a population-based study of nearly 3000 subjects over 10 years, men with snoring and excessive daytime sleepiness were more than twice as likely to have occupation-related accidents $(95 \%$ confidence interval $(\mathrm{CI})=$ 1.3-3.8) (Lindberg et al., 2001). It is also known that the quality of life (QOL) is lower in patients with severe OSA, and QOL substantially improves following clinical therapy such as continuous positive airway pressure (CPAP) (D'Ambrosio et al., 1999; Akashiba et al., 2002; Dutt et al., 2013). Recently, there is emerging evidence of associations of environmental factors such as air pollution on increased risks of OSA; however, the underlying mechanisms of this relationship remain uncertain.

It was estimated that the prevalence of OSA ranged from $9 \%$ to $37 \%$ in men and from $4 \%$ to 50\% in women (Franklin and Lindberg, 2015).

OSA is considered a multifactorial disease, including multiple genetic and environmental factors. Obesity is widely known as the most important risk factor for OSA. Older age, male 
gender and smoking is also strongly associated with a higher risk for OSA. This current review focused on risk factors for OSA and possible mechanisms related to air pollution.

\section{PREVALENCE OF OSA}

OSA is a common disorder characterized by recurrent episodes of nocturnal upper airway obstruction associated with repeated cycles of desaturation and re-oxygenation, leading to sleep fragmentation and consequent daytime sleepiness (Senaratna et al., 2017). OSA prevalence in adults more than 18 years of age, which is defined as a score of $\geq 5$ on the Apnea Hypopnea Index (AHI), ranged from 9\% (Reddy et al., 2009) to 38\% (Tufik et al., 2010). Data from the Wisconsin Sleep Cohort showed that almost $25 \%$ men and nearly $10 \%$ in women of 30-60 years of age had OSA (Young et al., 1993). In a cohort of more than 2000 subjects from Spain, an AHI of $\geq 5$ was found in $26 \%$ of men and $28 \%$ of women (Duran et al., 2001). A population-based study from Korea showed that the prevalence of OSA was more than one-fourth in men and $16 \%$ in women (Kim et al., 2004). The estimated prevalence of OSA in Hong Kong was $8.8 \%$ for men and 3.7\% for women (Ip et al., 2001; Ip et al., 2004), while the prevalence in India was 19.5\% (Udwadia et al., 2004). Interestingly, OSA occurs in roughly half of Swedish females aged 20-70 years old (Franklin et al., 2013). When using the American Academy of Sleep Medicine (AASM) 2012 diagnostic criteria, it is postulated that almost 1 billion adults in the world have OSA. Therefore, OSA is an important public health issue worldwide.

\section{RISK FACTORS FOR OSA}

Risk factors for OSA are shown in Fig. 1.

\subsection{Obesity}

Obesity is regarded as one of the strongest risk factors for OSA (Franklin et al., 2013). Since the obesity prevalence is growing globally (Punjabi, 2008; Garvey et al., 2015), it is likely that the OSA prevalence is also increasing (Peppard et al., 2013). A prospective cohort involving nearly 700 subjects found that a $10 \%$ increase in weight was associated with approximately a $33 \%$ increase in the AHI (Peppard et al., 2000). It is believed that the volume of parapharyngeal fatty tissue is related to the severity of OSA (Shelton et al., 1993). However, it is still controversial whether

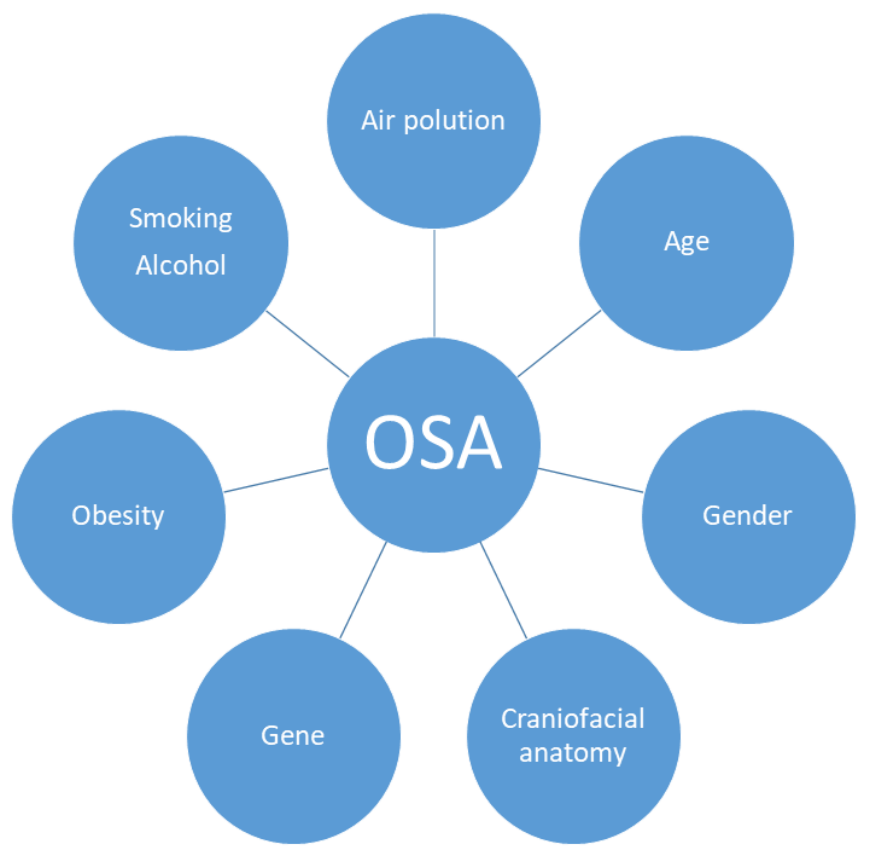

Fig. 1. Risk factors of OSA. 
neck or waist circumference is a better estimator of OSA compared to the body-mass index (BMI) alone (Young et al., 2005). A cross-sectional study of 85 male subjects found that the AHI was correlated with abdominal fat (Schafer et al., 2002). Nonetheless, data from the Sleep Heart Health Study showed that in addition to the BMI, neck circumference and waist circumference were also independent risk factors for severe OSA among middle-aged and older adults (Young et al., 2002). In a prospective study of more than 50 patients, Ogretmenoglu et al. (2005) found that the $\mathrm{BMI}$ and body fat percentage (determined by a bioelectrical impedance assay) were correlated with the AHI.

Obesity may contribute to OSA through several mechanisms (Punjabi, 2008). Parapharyngeal fat can cause airway narrowing and collapse (Schwartz et al., 2010). Leptin, a hormone produced by adipocytes and which is associated with the body composition, energy homeostasis and feeding behaviors, was significantly correlated with the AHI (Ulukavak Ciftci et al., 2005). The relationship between leptin resistance and obesity was mentioned in a previous study (Carter et al., 2013).

In a study of 18 subjects, patients with OSA had excess parapharyngeal fat deposition compared to non-OSA subjects as measured by the neck circumference (Mortimore et al., 1998). Katz et al. (1990) found that the only contributors to the AHI were the external neck circumference, BMI, and pharyngeal internal circumference. Similarly, a Turkish cross-sectional analysis of 1912 subjects showed that the neck circumference was of greater value than the waist circumference in the association with OSA among men (Onat et al., 2009).

\subsection{Age}

It was shown that an older age is associated with a higher OSA prevalence (Bixler et al., 1998; Gabbay and Lavie, 2012). This can be explained by an increase in parapharyngeal fat and an elongated soft palate (Malhotra et al., 2006). However, the OSA prevalence reaches a plateau after the age of 60 years (Bixler et al., 1998; Young et al., 2002), probably due to a smaller influence of BMI on elderly OSA subjects (Newman et al., 2005). Another possibility is that elderly patients with OSA have a higher mortality than those without OSA.

\subsection{Gender}

It is known that the prevalence of OSA in men is 2-3-fold higher than in women (Punjabi, 2008; Gabbay and Lavie, 2012; Ralls and Grigg-Damberger, 2012). In the Sleep Heart Health Study over a 5-year follow-up, men were more likely to have an increase in the Respiratory Disturbance Index (RDI) than were women (Young et al., 1993). This discrepancy may be explained by a sex difference in reporting symptoms of OSA, since women tend not to report common symptoms (loud snoring, cessation of breathing, and gasping), but instead report symptoms of fatigue and lack of energy (Young et al., 1997). Furthermore, it is more likely for men to be referred to OSA specialists because of the expectation of physicians that OSA predominantly affects men. Sex hormones are also likely to be important in OSA, as the disorder is more common in postmenopausal women (Ralls and Grigg-Damberger, 2012). However, hormone replacement can reduce the severity of OSA in those patients (Shahar et al., 2003; Wesstrom et al., 2005).

\subsection{Craniofacial Anatomy}

It was shown that different craniofacial morphologies are correlated with OSA severity (Fan and Liu, 2010; Vidovic et al., 2013; Fernandez-Salvador et al., 2018; Sutherland et al., 2018). For example, brachycephaly was a strong risk factor for high AHI scores in a white population (Cakirer et al., 2001), while Chinese patients with OSA had retrognathia or micrognathia (Lam et al., 2005). The mechanism for this phenomenon is that several craniofacial morphologies can change the airway shape and increase the likelihood of its collapse during sleep. Furthermore, tonsillar hypertrophy or an enlarged base of the tongue can also result in upper airway narrowing and cause OSA (Schwab, 2003).

\subsection{Smoking and Alcohol}

Current smoking, ex-smoking, and active and passive smoking are all strong factors for snoring and OSA (Khoo et al., 2004; Quan et al., 2014; Varol et al., 2015; Bielicki et al., 2019). Smoking 
can result in OSA through airway narrowing, inflammation, and collapsibility during sleep (Pack et al., 1992; Kim et al., 2012). Alcohol consumption before sleep can also cause airway collapse and consequent OSA. Drinkers have an increased odds ratio (OR) of almost 1.33 times $(95 \% \mathrm{Cl}$; 1.10-1.62) for OSA compared to non-drinkers (Taveira et al., 2018). However, the mechanisms for this collapse are still unclear. Experimental studies in animals (Bonora et al., 1984) and humans (Krol et al., 1984) showed that alcohol causes hypotonia of the oropharyngeal muscles by decreasing respiratory activity in the upper airway.

\subsection{Genetic Inheritance}

Several studies researched the role of genetic factors in the genesis of OSA. Segregation analyses showed that inherited factors can contribute to approximately $35 \%$ of the variance in OSA severity. Susceptibility loci for OSA were identified in genome-wide association scans (Patel et al., 2012; Yin et al., 2014; Zhang et al., 2014; Gok et al., 2015; Cade et al., 2016), which showed an association of genetic loci and OSA in African-American and European-American subjects (Patel et al., 2012).

\subsection{Air Pollution}

Air pollution is known to be an important risk factor for cardiopulmonary disease; however, few studies have investigated the effects of air pollution on OSA. In a study of over 3000 subjects from the Sleep Heart Health Study, an increased RDI and decreased sleep efficiency were associated with short-term augmentation in particulate matter (PM) of $\leq 10 \mu \mathrm{m}$ in aerodynamic diameter $\left(\mathrm{PM}_{10}\right)$ and temperature in the summer (Zanobetti et al., 2010). Another populationbased study of nearly 2000 adults of 45-84 years of age in six cities of the USA from the MultiEthnic Study of Atherosclerosis showed that an increase in annual nitrogen dioxide $\left(\mathrm{NO}_{2}\right)$ and PM of $\leq 2.5 \mu \mathrm{m}$ in aerodynamic diameter $\left(\mathrm{PM}_{2.5}\right)$ was correlated with an increased OR of sleep apnea (Billings et al., 2019). Specifically, each $5-\mu \mathrm{g} \mathrm{m}^{-3}$ per year increase in $\mathrm{PM}_{2.5}$ led to a $60 \%$ higher OR of OSA. Similarly, a large population-based study of more than 4000 individuals in Taiwan also showed an association of 1-year $\mathrm{PM}_{2.5}$ and $\mathrm{NO}_{2}$ exposure with the $\mathrm{AHI}$, which was greater during spring and winter (Shen et al., 2018). In a retrospective study of more than 7000 subjects, the $\mathrm{AHI}$ was associated with atmospheric pressure and carbon monoxide (CO) exposure (Cassol et al., 2012). Those authors found that OSA were more prevalent in winter than in other seasons. Interestingly, short-term elevated ozone $\left(\mathrm{O}_{3}\right)$ and temperature resulted in an increased $\mathrm{AHI}$ in a European study (Weinreich et al., 2015). A study of more than 5000 subjects in Taiwan from 2008 to 2015 showed that $\mathrm{PM}_{10}, \mathrm{O}_{3}$, sulfur dioxide $\left(\mathrm{SO}_{2}\right)$, and humidity were only associated with severe OSA in the non-rapid eye movement sleep period (Cheng et al., 2019).

\section{ALTERATIONS IN THE PERMEABILITY OF AIRWAY BY PM}

Several studies researched the relationship between a shift in body fluids and OSA in healthy people (Redolfi et al., 2009), and in those with heart failure (Yumino et al., 2010), hypertension (Friedman et al., 2010), and renal failure (Elias et al., 2012). The fact that non-obese patients wearing compression stockings during the day can decrease the AHI suggests a causative role of an overnight fluid shift in OSA (Silva et al., 2017). A study of 36 subjects showed that patients with OSA had more baseline leg fluid than non-OSA patients, which suggests a greater fluid shift in OSA patients (Ding et al., 2014). According to White, during the day, fluid is retained in the legs due to gravity. During night sleep, the fluid is redistributed to the neck also due to gravity, which leads to airway narrowing and consequent OSA (White and Bradley, 2013).

The mechanism for the rostral fluid shift can be explained by Starling's force. Patients with heart failure have high venous pressure, which results in more fluid being retained in the legs during the daytime. Consequently, when a patient lies down, more fluid in the legs will shift into the neck and cause OSA. Similarly, patients with a low protein state, which means low colloid osmotic pressure, will exhibit edema. However, edema also appears in healthy OSA patients, suggesting that OSA can lead to edema (Iftikhar et al., 2008). The mechanism is still unclear and might be explained by an increase in the atrial natriuretic peptide (Kita et al., 1998) and the activation of the renin-angiotensin-aldosterone system. 
The association between airway permeability and air pollution was investigated in previous studies. High concentrations of diesel exhaust particles (DEPs) reduce occludin messenger RNA, which has an important role in maintaining the epithelial barrier integrity (Lehmann et al., 2009). $\mathrm{PM}_{10}$ also reduces occludin expression and increases alveolar transepithelial electrical conductance (Caraballo et al., 2011). Cadmium, a chemical element present in air pollutants, was shown to disrupt tight junction integrity (Cao et al., 2015) in vitro via modulating genes associated with tight junctions. $\mathrm{PM}_{2.5}$ also disrupts the nasal epithelial barrier via degradation of tight junction proteins (Zhao et al., 2018). $\mathrm{PM}_{2.5}$ is associated with Clara Cell Protein (CC16), a marker of epithelial barrier permeability (Timonen et al., 2004; Jacquemin et al., 2009) in adolescents (Provost et al., 2014) and elderly men (Madsen et al., 2008). Together, changes in permeability caused by air pollution could be an important pathophysiology of airway disease.

\section{POSSIBLE MECHANISMS OF PM IN OSA}

The mechanism of OSA by PM may be explained by oxidative stress and inflammation (Fig. 2). The composition of particles is very important for their toxicity. Thus, transition metals such as iron, copper, nickel, chromium, and vanadium can increase reactive oxygen species (ROS). Furthermore, volatile organic compounds (quinones and polycyclic aromatic hydrocarbons) in PM cause the production of ROS in neutrophils, eosinophils, macrophages, and bronchial epithelial cells. Normally, homeostasis in the body keeps oxidizing substances such as ROS and antioxidant defense mechanisms in a balanced state. However, when there are excess ROS generated during mitochondrial oxidative metabolism, oxidative stress occurs. This phenomenon leads to oxidative lipid degradation, protein oxidation, and consequent inflammation. $\mathrm{PM}_{2.5}$ was reported to increase ROS in human nasal epithelial cells and decrease the viability of those cells (Hong et al., 2016).

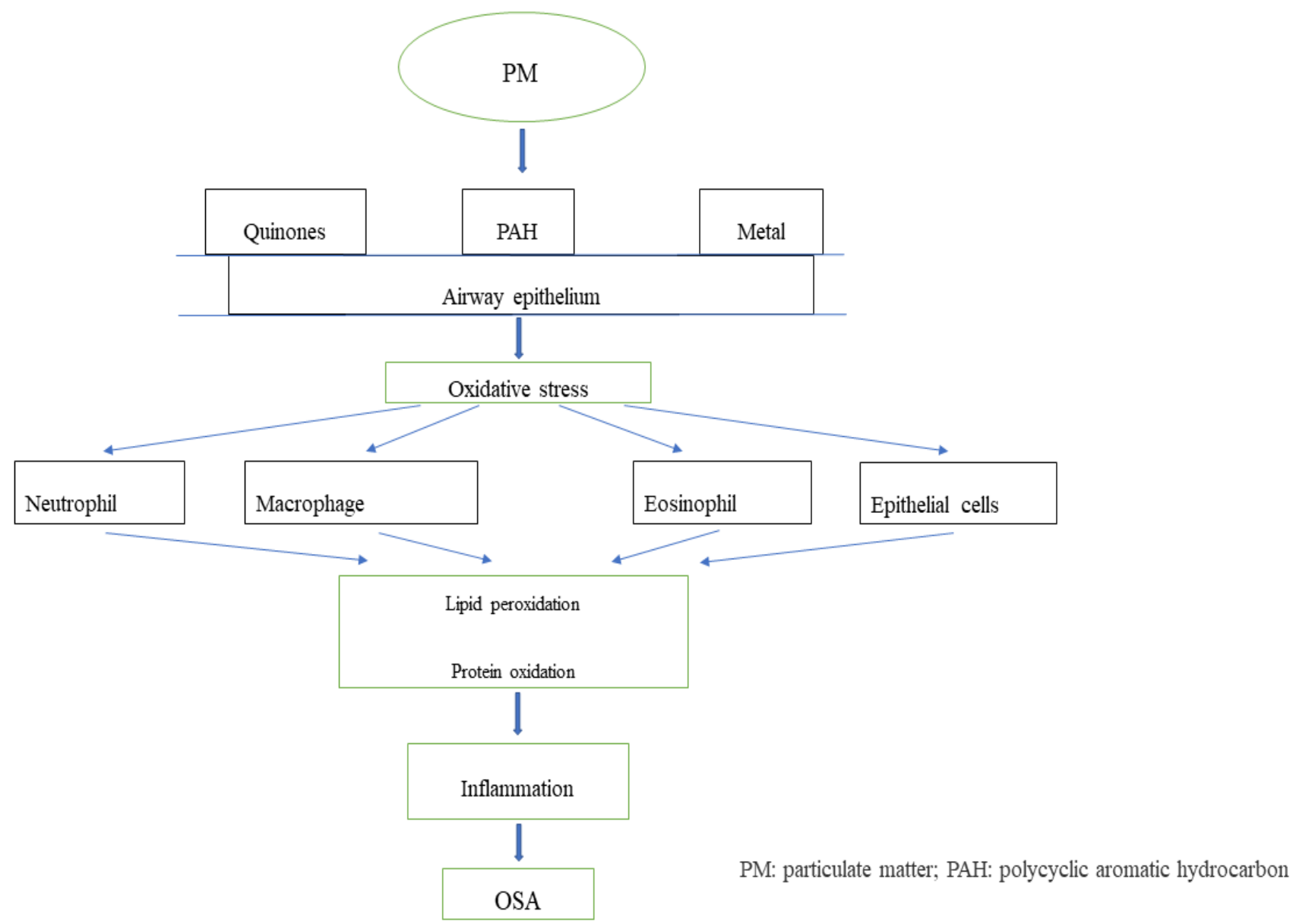

Fig. 2. The possible mechanisms of OSA by particulate matter. 
PM-related oxidative stress and inflammation leads to hyperpermeability in the human upper airway and subsequent airway obstruction, thus causing OSA. Exposure to $\mathrm{PM}_{2.5}$ also led to barrier disruption in the human epithelium by reducing expressions of tight junction proteins and increasing the secretion of inflammatory cytokines, which result in allergic rhinitis and rhinosinusitis (Zhao et al., 2018; Kim et al., 2019; Xian et al., 2020). Furthermore, disruption of tight junctions by DEPs via a ROS-mediated pathway resulted in greater permeability of nasal epithelial cells and seasonal allergic rhinitis as observed in an animal model (Fukuoka et al., 2016). PM 2.5 also caused hypersecretion in the rat airway (Harkema et al., 2004). A study in China found a significant association of $\mathrm{PM}_{2.5}$ and $\mathrm{PM}_{10}$ exposure with the prevalence of allergic rhinitis (Teng et al., 2017).

\section{CONCLUSIONS}

This review paper demonstrates an association of air pollution and respiratory permeability in OSA. There is now considerable evidence that fluid accumulation in the legs during the daytime and the overnight fluid shift is a risk factor for OSA. Furthermore, airway permeability changes by air pollution play important roles in the pathogenesis of airway diseases. Further work is required to better understand patterns of fluid shifts in OSA and to completely elucidate the mechanisms of air pollution causing OSA.

\section{ACKNOWLEDGEMENTS}

This study was funded by the Ministry of Science and Technology of Taiwan (109-2314-B-038093-MY3).

\section{DISCLAIMER}

The authors declare that they have no conflicts of interest.

\section{REFERENCES}

Akashiba, T., Kawahara, S., Akahoshi, T., Omori, C., Saito, O., Majima, T., Horie, T. (2002). Relationship between quality of life and mood or depression in patients with severe obstructive sleep apnea syndrome. Chest 122, 861-865. https://doi.org/10.1378/chest.122.3. 861

AIGhanim, N., Comondore, V.R., Fleetham, J., Marra, C.A., Ayas, N.T. (2008). The economic impact of obstructive sleep apnea. Lung 186, 7-12. https://doi.org/10.1007/s00408-007-9055-5

Bielicki, P., Trojnar, A., Sobieraj, P., Wasik, M. (2019). Smoking status in relation to obstructive sleep apnea severity (OSA) and cardiovascular comorbidity in patients with newly diagnosed OSA. Adv. Respir. Med. 87, 103-109. https://doi.org/10.5603/ARM.a2019.0011

Billings, M.E., Gold, D., Szpiro, A., Aaron, C.P., Jorgensen, N., Gassett, A., Leary, P.J., Kaufman, J.D., Redline, S.R. (2019). The association of ambient air pollution with sleep apnea: The multiethnic study of atherosclerosis. Ann. Am. Thorac. Soc. 16, 363-370. https://doi.org/10.1513/ AnnalsATS.201804-2480C

Bixler, E.O., Vgontzas, A.N., Ten Have, T., Tyson, K., Kales, A. (1998). Effects of age on sleep apnea in men: I. Prevalence and severity. Am. J. Respir. Crit. Care. Med. 157, 144-148. https://doi.org/10.1164/ajrccm.157.1.9706079

Bonora, M., Shields, G.I., Knuth, S.L., Bartlett, D., Jr., St John, W.M. (1984). Selective depression by ethanol of upper airway respiratory motor activity in cats. Am. Rev. Respir. Dis. 130, 156161. https://doi.org/10.1164/arrd.1984.130.2.156

Cade, B.E., Chen, H., Stilp, A.M., Gleason, K.J., Sofer, T., Ancoli-Israel, S., Arens, R., Bell, G.I., Below, J.E., Bjonnes, A.C., Chun, S., Conomos, M.P., Evans, D.S., Johnson, W.C., Frazier-Wood, A.C., Lane, J.M., Larkin, E.K., Loredo, J.S., Post, W.S., ... Redline, S. (2016). Genetic associations with obstructive sleep apnea traits in Hispanic/Latino Americans. Am. J. Respir. Crit. Care. Med. 194, 886-897. https://doi.org/10.1164/rccm.201512-24310C 
Cakirer, B., Hans, M.G., Graham, G., Aylor, J., Tishler, P.V., Redline, S. (2001). The relationship between craniofacial morphology and obstructive sleep apnea in whites and in African-Americans Am. J. Respir. Crit. Care. Med. 163, 947-950. https://doi.org/10.1164/ajrccm.163.4.2005136

Cao, X., Lin, H., Muskhelishvili, L., Latendresse, J., Richter, P., Heflich, R.H. (2015). Tight junction disruption by cadmium in an in vitro human airway tissue model. Respir. Res. 16, 30. https://doi.org/10.1186/s12931-015-0191-9

Caraballo, J.C., Yshii, C., Westphal, W., Moninger, T., Comellas, A.P. (2011). Ambient particulate matter affects occludin distribution and increases alveolar transepithelial electrical conductance. Respirology 16, 340-349. https://doi.org/10.1111/j.1440-1843.2010.01910.x

Carter, S., Caron, A., Richard, D., Picard, F. (2013). Role of leptin resistance in the development of obesity in older patients. Clin. Interv. Aging 8, 829-844. https://doi.org/10.2147/CIA.S36367

Cassol, C.M., Martinez, D., da Silva, F., Fischer, M.K., Lenz, M., Bos, A.J.G. (2012). Is sleep apnea a winter disease?: Meteorologic and sleep laboratory evidence collected over 1 decade. Chest 142, 1499-1507. https://doi.org/10.1378/chest.11-0493

Cheng, W.J., Liang, S.J., Huang, C.S., Lin, C.L., Pien, L.C., Hang, L.W. (2019). Air pollutants are associated with obstructive sleep apnea severity in non-rapid eye movement sleep. J. Clin. Sleep Med. 15, 831-837. https://doi.org/10.5664/jcsm.7830

D'Ambrosio, C., Bowman, T., Mohsenin, V. (1999). Quality of life in patients with obstructive sleep apnea: Effect of nasal continuous positive airway pressure--A prospective study. Chest 115, 123-129. https://doi.org/10.1378/chest.115.1.123

Ding, N., Lin, W., Zhang, X.L., Ding, W.X., Gu, B., Ni, B.Q., Zhang, W., Zhang, S.J., Wang, H. (2014). Overnight fluid shifts in subjects with and without obstructive sleep apnea. J. Thorac. Dis. 6, 1736-1741. https://doi.org/10.3978/j.issn.2072-1439.2014.11.19

Duran, J., Esnaola, S., Rubio, R., Iztueta, A. (2001). Obstructive sleep apnea-hypopnea and related clinical features in a population-based sample of subjects aged 30 to $70 \mathrm{yr}$. Am. J. Respir. Crit. Care. Med. 163, 685-689. https://doi.org/10.1164/ajrccm.163.3.2005065

Dutt, N., Janmeja, A.K., Mohapatra, P.R., Singh, A.K. (2013). Quality of life impairment in patients of obstructive sleep apnea and its relation with the severity of disease. Lung India 30, 289-294. https://doi.org/10.4103/0970-2113.120603

Elias, R.M., Bradley, T.D., Kasai, T., Motwani, S.S., Chan, C.T. (2012). Rostral overnight fluid shift in end-stage renal disease: Relationship with obstructive sleep apnea. Nephrol. Dial. Transplant. 27, 1569-1573. https://doi.org/10.1093/ndt/gfr605

Fan, Y., Liu, L. (2010). Relationship between adult craniofacial structures and development of obstructive sleep apnea-hypopnea syndrome. Lin Chung Er Bi Yan Hou Tou Jing Wai Ke Za Zhi 24, 502-505.

Fernandez-Salvador, C., Song, S.A., Chang, E.T., Camacho, M. (2018). Human craniofacial evolution: A cause for obstructive sleep apnea. Cranio 36, 1-2. https://doi.org/10.1080/08869 634.2018.1405628

Franklin, K.A., Sahlin, C., Stenlund, H., Lindberg, E. (2013). Sleep apnoea is a common occurrence in females. Eur. Respir. J. 41, 610-615. https://doi.org/10.1183/09031936.00212711

Franklin, K.A., Lindberg, E. (2015). Obstructive sleep apnea is a common disorder in the population-A review on the epidemiology of sleep apnea. J. Thorac. Dis. 7, 1311-1322. https://doi.org/10.3978/j.issn.2072-1439.2015.06.11

Friedman, O., Bradley, T.D., Chan, C.T., Parkes, R., Logan, A.G. (2010). Relationship between overnight rostral fluid shift and obstructive sleep apnea in drug-resistant hypertension. Hypertension 56, 1077-1082. https://doi.org/10.1161/HYPERTENSIONAHA.110.154427

Fukuoka, A., Matsushita, K., Morikawa, T., Takano, H., Yoshimoto, T. (2016). Diesel exhaust particles exacerbate allergic rhinitis in mice by disrupting the nasal epithelial barrier. Clin. Exp. Allergy 46, 142-152. https://doi.org/10.1111/cea.12597

Gabbay, I.E., Lavie, P. (2012). Age- and gender-related characteristics of obstructive sleep apnea. Sleep Breath. 16, 453-460. https://doi.org/10.1007/s11325-011-0523-z

Garvey, J.F., Pengo, M.F., Drakatos, P., Kent, B.D. (2015). Epidemiological aspects of obstructive sleep apnea. J. Thorac. Dis. 7, 920-929. https://doi.org/10.3978/j.issn.2072-1439.2015.04.52

Gok, I., Huseyinoglu, N., Ilhan, D. (2015). Genetic polymorphisms variants in interleukin-6 and interleukin-1beta patients with obstructive sleep apnea syndrome in East Northern Turkey. Med. Glas. 12, 216-222. https://doi.org/10.17392/804-15 
Harkema, J.R., Keeler, G., Wagner, J., Morishita, M., Timm, E., Hotchkiss, J., Marsik, F., Dvonch, T., Kaminski, N., Barr, E. (2004). Effects of concentrated ambient particles on normal and hypersecretory airways in rats. Res. Rep. Health Eff. Inst. 120, 1-68.

Hong, Z., Guo, Z., Zhang, R., Xu, J., Dong, W., Zhuang, G., Deng, C. (2016). Airborne fine particulate matter induces oxidative stress and inflammation in human nasal epithelial cells. Tohoku J. Exp. Med. 239, 117-125. https://doi.org/10.1620/tjem.239.117

Iftikhar, I., Ahmed, M., Tarr, S., Zyzanski, S.J., Blankfield, R.P. (2008). Comparison of obstructive sleep apnea patients with and without leg edema. Sleep Med. 9, 890-893. https://doi.org/10. 1016/j.sleep.2007.10.019

Ip, M.S., Lam, B., Lauder, I.J., Tsang, K.W., Chung, K.F., Mok, Y.W., Lam, W.K. (2001). A community study of sleep-disordered breathing in middle-aged chinese men in Hong Kong. Chest 119, 6269. https://doi.org/10.1378/chest.119.1.62

Ip, M.S.M., Lam, B., Tang, L.C.H., Lauder, I.J., Ip, T.Y., Lam, W.K. (2004). A community study of sleep-disordered breathing in middle-aged chinese women in Hong Kong: Prevalence and gender differences. Chest 125, 127-134. https://doi.org/10.1378/chest.125.1.127

Jacquemin, B., Lanki, T., Yli-Tuomi, T., Vallius, M., Hoek, G., Heinrich, J., Timonen, K., Pekkanen, J. (2009). Source category-specific $\mathrm{PM}_{2.5}$ and urinary levels of Clara cell protein CC16. The ULTRA study. Inhalation Toxicol. 21, 1068-1076. https://doi.org/10.3109/08958370902725292

Kapur, V.K. (2010). Obstructive sleep apnea: Diagnosis, and epidemiology, economics. Respir. Care 55, 1155-1167.

Katz, I., Stradling, J., Slutsky, A.S., Zamel, N., Hoffstein, V. (1990). Do patients with obstructive sleep apnea have thick necks? Am. Rev. Respir. Dis. 141, 1228-1231. https://doi.org/10.1164/ ajrccm/141.5_Pt_1.1228

Khoo, S.M., Tan, W.C., Ng, T.P., Ho, C.H. (2004). Risk factors associated with habitual snoring and sleep-disordered breathing in a multi-ethnic Asian population: A population-based study. Respir. Med. 98, 557-566. https://doi.org/10.1016/j.rmed.2003.11.017

Kim, J., In, K., Kim, J., You, S., Kang, K., Shim, J., Lee, S., Lee, J., Lee, S., Park, C., Shin, C. (2004). Prevalence of sleep-disordered breathing in middle-aged Korean men and women. Am. J. Respir. Crit. Care. Med. 170, 1108-1113. https://doi.org/10.1164/rccm.200404-5190C

Kim, K.S., Kim, J.H., Park, S.Y., Won, H.R., Lee, H.J., Yang, H.S., Kim, H.J. (2012). Smoking induces oropharyngeal narrowing and increases the severity of obstructive sleep apnea syndrome. J. Clin. Sleep Med. 8, 367-374. https://doi.org/10.5664/jcsm.2024

Kim, N., Han, D.H., Suh, M.W., Lee, J.H., Oh, S.H., Park, M.K. (2019). Effect of lipopolysaccharide on diesel exhaust particle-induced junctional dysfunction in primary human nasal epithelial cells. Environ. Pollut. 248, 736-742. https://doi.org/10.1016/j.envpol.2019.02.082

Kita, H., Ohi, M., Chin, K., Noguchi, T., Otsuka, N., Tsuboi, T., Itoh, H., Nakao, K., Kuno, K. (1998). The nocturnal secretion of cardiac natriuretic peptides during obstructive sleep apnoea and its response to therapy with nasal continuous positive airway pressure. J. Sleep Res. 7, 199-207. https://doi.org/10.1046/j.1365-2869.1998.00109.x

Knauert, M., Naik, S., Gillespie, M.B., Kryger, M. (2015). Clinical consequences and economic costs of untreated obstructive sleep apnea syndrome. World J. Otorhinolaryngol. Head Neck Surg. 1, 17-27. https://doi.org/10.1016/j.wjorl.2015.08.001

Krol, R.C., Knuth, S.L., Jr, B.D. (1984). Selective reduction of genioglossal muscle activity by alcohol in normal human subjects. Am. Rev. Respir. Dis. 129, 247-250.

Lam, B., Ip, M.S.M., Tench, E., Ryan, C.F. (2005). Craniofacial profile in Asian and white subjects with obstructive sleep apnoea. Thorax 60, 504-510. https://doi.org/10.1136/thx.2004.031591

Lehmann, A.D., Blank, F., Baum, O., Gehr, P., Rothen-Rutishauser, B.M. (2009). Diesel exhaust particles modulate the tight junction protein occludin in lung cells in vitro. Part. Fibre Toxicol. 6, 26. https://doi.org/10.1186/1743-8977-6-26

Lindberg, E., Carter, N., Gislason, T., Janson, C. (2001). Role of snoring and daytime sleepiness in occupational accidents. Am. J. Respir. Crit. Care. Med. 164, 2031-2035. https://doi.org/10.116 4/ajrccm.164.11.2102028

Madsen, C., Durand, K.L., Nafstad, P., Schwarze, P.E., Ronningen, K.S., Haheim, L.L. (2008). Associations between environmental exposures and serum concentrations of clara cell protein among elderly men in Oslo, Norway. Environ. Res. 108, 354-360. https://doi.org/10.1016/j.en vres.2008.07.017 
Malhotra, A., Huang, Y., Fogel, R., Lazic, S., Pillar, G., Jakab, M., Kikinis, R., White, D.P. (2006). Aging influences on pharyngeal anatomy and physiology: The predisposition to pharyngeal collapse. Am. J. Med. 119, 72.e9-72.e14. https://doi.org/10.1016/j.amjmed.2005.01.077

Mortimore, I.L., Marshall, I., Wraith, P.K., Sellar, R.J., Douglas, N.J. (1998). Neck and total body fat deposition in nonobese and obese patients with sleep apnea compared with that in control subjects. Am. J. Respir. Crit. Care. Med. 157, 280-283. https://doi.org/10.1164/ajrccm.157.1.9 703018

Newman, A.B., Foster, G., Givelber, R., Nieto, F.J., Redline, S., Young, T. (2005). Progression and regression of sleep-disordered breathing with changes in weight: The Sleep Heart Health Study. Arch. Intern. Med. 165, 2408-2413. https://doi.org/10.1001/archinte.165.20.2408

Öğretmenoğlu, O., Süslü, A.E., Yücel, Ö.T., Önerci, T.M., Şahin, A. (2005). Body fat composition: A predictive factor for obstructive sleep apnea. Laryngoscope 115, 1493-1498. https://doi.org/10.1097/01.mlg.0000172204.82314.c3

Onat, A., Hergenc, G., Yuksel, H., Can, G., Ayhan, E., Kaya, Z., Dursunoglu, D. (2009). Neck circumference as a measure of central obesity: Associations with metabolic syndrome and obstructive sleep apnea syndrome beyond waist circumference. Clin. Nutr. 28, 46-51. https://doi.org/10.1016/j.clnu.2008.10.006

Pack, A.I., Cola, M.F., Goldszmidt, A., Ogilvie, M.D., Gottschalk, A. (1992). Correlation between oscillations in ventilation and frequency content of the electroencephalogram. J. Appl. Physiol. 72, 985-992. https://doi.org/10.1152/jappl.1992.72.3.985

Patel, S.R., Goodloe, R., De, G., Kowgier, M., Weng, J., Buxbaum, S.G., Cade, B., Fulop, T., Gharib, S.A., Gottlieb, D.J., Hillman, D., Larkin, E.K., Lauderdale, D.S., Li, L., Mukherjee, S., Palmer, L., Zee, P., Zhu, X., Redline, S. (2012). Association of genetic loci with sleep apnea in European Americans and African-Americans: The Candidate Gene Association Resource (CARe). PLoS One 7, e48836. https://doi.org/10.1371/journal.pone.0048836

Peppard, P.E., Young, T., Palta, M., Dempsey, J., Skatrud, J. (2000). Longitudinal study of moderate weight change and sleep-disordered breathing. JAMA 284, 3015-3021. https://doi.org/10.1001/jama.284.23.3015

Peppard, P.E., Young, T., Barnet, J.H., Palta, M., Hagen, E.W., Hla, K.M. (2013). Increased prevalence of sleep-disordered breathing in adults. Am. J. Epidemiol. 177, 1006-1014. https://doi.org/10.1093/aje/kws342

Provost, E.B., Chaumont, A., Kicinski, M., Cox, B., Fierens, F., Bernard, A., Nawrot, T.S. (2014). Serum levels of club cell secretory protein (Clara) and short- and long-term exposure to particulate air pollution in adolescents. Environ. Int. 68, 66-70. https://doi.org/10.1016/j.envi nt.2014.03.011

Punjabi, N.M. (2008). The epidemiology of adult obstructive sleep apnea. Proc. Am. Thorac. Soc. 5, 136-143. https://doi.org/10.1513/pats.200709-155MG

Quan, Z., Liu, J., Xie, Y., Lei, Z., Liang, B., Jiang, L., Tang, H. (2014). [correlation of smoking and obstructive sleep apnea and hypopnea syndrome]. Zhonghua Yi Xue Za Zhi 94: 733-736.

Ralls, F.M., Grigg-Damberger, M. (2012). Roles of gender, age, race/ethnicity, and residential socioeconomics in obstructive sleep apnea syndromes. Curr. Opin. Pulm. Med. 18, 568-573. https://doi.org/10.1097/MCP.0b013e328358be05

Reddy, E.V., Kadhiravan, T., Mishra, H.K., Sreenivas, V., Handa, K.K., Sinha, S., Sharma, S.K. (2009). Prevalence and risk factors of obstructive sleep apnea among middle-aged urban Indians: A community-based study. Sleep Med. 10, 913-918. https://doi.org/10.1016/j.sleep.2008.08.011

Redolfi, S., Yumino, D., Ruttanaumpawan, P., Yau, B., Su, M.C., Lam, J., Bradley, T.D. (2009). Relationship between overnight rostral fluid shift and obstructive sleep apnea in nonobese men. Am. J. Respir. Crit. Care. Med. 179, 241-246. https://doi.org/10.1164/rccm.200807-10760C

Schafer, H., Pauleit, D., Sudhop, T., Gouni-Berthold, I., Ewig, S., Berthold, H.K. (2002). Body fat distribution, serum leptin, and cardiovascular risk factors in men with obstructive sleep apnea. Chest 122, 829-839. https://doi.org/10.1378/chest.122.3.829

Schwab, R.J. (2003). Pro: Sleep apnea is an anatomic disorder. Am. J. Respir. Crit. Care. Med. 168, 270-271. https://doi.org/10.1164/rccm.2305014

Schwartz, A.R., Patil, S.P., Squier, S., Schneider, H., Kirkness, J.P., Smith, P.L. (2010). Obesity and upper airway control during sleep. J. Appl. Physiol. 108, 430-435. https://doi.org/10.1152/jap plphysiol.00919.2009 
Senaratna, C.V., Perret, J.L., Lodge, C.J., Lowe, A.J., Campbell, B.E., Matheson, M.C., Hamilton, G.S., Dharmage, S.C. (2017). Prevalence of obstructive sleep apnea in the general population: A systematic review. Sleep Med. Rev. 34, 70-81. https://doi.org/10.1016/j.smrv.2016.07.002

Shahar, E., Redline, S., Young, T., Boland, L.L., Baldwin, C.M., Nieto, F.J., O'Connor, G.T., Rapoport, D.M., Robbins, J.A. (2003). Hormone replacement therapy and sleep-disordered breathing. Am. J. Respir. Crit. Care. Med. 167, 1186-1192. https://doi.org/10.1164/rccm.200210-12380C

Shelton, K.E., Woodson, H., Gay, S., Suratt, P.M. (1993). Pharyngeal fat in obstructive sleep apnea. Am. Rev. Respir. Dis. 148, 462-466. https://doi.org/10.1164/ajrccm/148.2.462

Shen, Y.L., Liu, W.T., Lee, K.Y., Chuang, H.C., Chen, H.W., Chuang, K.J. (2018). Association of PM2.5 with sleep-disordered breathing from a population-based study in northern Taiwan urban areas. Environ. Pollut. 233, 109-113. https://doi.org/10.1016/j.envpol.2017.10.052

Sherman, B. (2013). Obstructive sleep apnea and health benefits purchasing: An employer perspective. J. Clin. Sleep Med. 9, 187-189. https://doi.org/10.5664/jcsm.2472

Silva, B.C., Santos, R.S.S., Drager, L.F., Coelho, F.M., Elias, R.M. (2017). Impact of compression stockings vs. Continuous positive airway pressure on overnight fluid shift and obstructive sleep apnea among patients on hemodialysis. Front. Med. 4, 57. https://doi.org/10.3389/fmed.201 7.00057

Sutherland, K., Lee, R.W.W., Chan, T.O., Ng, S., Hui, D.S., Cistulli, P.A. (2018). Craniofacial phenotyping in Chinese and caucasian patients with sleep apnea: Influence of ethnicity and sex. J. Clin. Sleep Med. 14, 1143-1151. https://doi.org/10.5664/jcsm.7212

Taveira, K.V.M., Kuntze, M.M., Berretta, F., de Souza, B.D.M., Godolfim, L.R., Demathe, T., De Luca Canto, G., Porporatti, A.L. (2018). Association between obstructive sleep apnea and alcohol, caffeine and tobacco: A meta-analysis. J. Oral Rehabil. 45, 890-902. https://doi.org/10. 1111/joor.12686

Teng, B., Zhang, X., Yi, C., Zhang, Y., Ye, S., Wang, Y., Tong, D.Q., Lu, B. (2017). The association between ambient air pollution and allergic rhinitis: Further epidemiological evidence from Changchun, northeastern China. Int. J. Environ. Res. Public Health. 14, 226. https://doi.org/10.3390/ijerph14030226

Timonen, K.L., Hoek, G., Heinrich, J., Bernard, A., Brunekreef, B., de Hartog, J., Hameri, K., IbaldMulli, A., Mirme, A., Peters, A., Tiittanen, P., Kreyling, W.G., Pekkanen, J. (2004). Daily variation in fine and ultrafine particulate air pollution and urinary concentrations of lung Clara cell protein CC16. Occup. Environ. Med. 61, 908-914. https://doi.org/10.1136/oem.2004.012849

Tufik, S., Santos-Silva, R., Taddei, J.A., Bittencourt, L.R.A. (2010). Obstructive sleep apnea syndrome in the Sao Paulo Epidemiologic Sleep Study. Sleep Med. 11, 441-446. https://doi.org/10.1016/j.sleep.2009.10.005

Udwadia, Z.F., Doshi, A.V., Lonkar, S.G., Singh, C.I. (2004). Prevalence of sleep-disordered breathing and sleep apnea in middle-aged urban Indian men. Am. J. Respir. Crit. Care. Med. 169, 168-173. https://doi.org/10.1164/rccm.200302-2650C

Ulukavak Ciftci, T., Kokturk, O., Bukan, N., Bilgihan, A. (2005). Leptin and ghrelin levels in patients with obstructive sleep apnea syndrome. Respiration 72, 395-401. https://doi.org/10.1159/00 0086254

Varol, Y., Anar, C., Tuzel, O.E., Guclu, S.Z., Ucar, Z.Z. (2015). The impact of active and former smoking on the severity of obstructive sleep apnea. Sleep Breath. 19, 1279-1284. https://doi.org/10.1007/s11325-015-1159-1

Vidovic, N., Mestrovic, S., Dogas, Z., Bukovic, D., Brakus, I., Brakus, R.B., Kovacic, I. (2013). Craniofacial morphology of croatian patients with obstructive sleep apnea. Coll. Antropol. 37, 271-279.

Weinreich, G., Wessendorf, T.E., Pundt, N., Weinmayr, G., Hennig, F., Moebus, S., Möhlenkamp, S., Erbel, R., Jöckel, K.-H., Teschler, H., Hoffmann, B. (2015). Association of short-term ozone and temperature with sleep disordered breathing. Eur. Respir. J. 46, 1361-1369. https://doi.org/10.1183/13993003.02255-2014

Wesstrom, J., Ulfberg, J., Nilsson, S. (2005). Sleep apnea and hormone replacement therapy: A pilot study and a literature review. Acta Obstet. Gynecol. Scand. 84, 54-57. https://doi.org/10. 1111/j.0001-6349.2005.00575.x

White, L.H., Bradley, T.D. (2013). Role of nocturnal rostral fluid shift in the pathogenesis of obstructive and central sleep apnoea. J. Physiol. 591, 1179-1193. https://doi.org/10.1113/jph ysiol.2012.245159 
Xian, M., Ma, S., Wang, K., Lou, H., Wang, Y., Zhang, L., Wang, C., Akdis, C.A. (2020). Particulate matter 2.5 causes deficiency in barrier integrity in human nasal epithelial cells. Allergy Asthma Immunol. Res. 12, 56-71. https://doi.org/10.4168/aair.2020.12.1.56

Yin, T., Li, N.F., Heizhati, M., Zhang, J., Zhang, J., Zhou, L., Chang, G. (2014). Association of glucose transporter 4 genetic polymorphisms with obstructive sleep apnea syndrome in Han Chinese general population: A cross-section study. Lipids Health Dis. 13, 12. https://doi.org/10.1186/1 476-511X-13-12

Young, T., Palta, M., Dempsey, J., Skatrud, J., Weber, S., Badr, S. (1993). The occurrence of sleepdisordered breathing among middle-aged adults. N. Engl. J. Med. 328, 1230-1235. https://doi.org/10.1056/NEJM199304293281704

Young, T., Evans, L., Finn, L., Palta, M. (1997). Estimation of the clinically diagnosed proportion of sleep apnea syndrome in middle-aged men and women. Sleep 20, 705-706. https://doi.org/1 0.1093/sleep/20.9.705

Young, T., Shahar, E., Nieto, F.J., Redline, S., Newman, A.B., Gottlieb, D.J., Walsleben, J.A., Finn, L., Enright, P., Samet, J.M., Sleep Heart Health Study Research Group (2002). Predictors of sleep-disordered breathing in community-dwelling adults: The Sleep Heart Health Study. Arch. Intern. Med. 162, 893-900. https://doi.org/10.1001/archinte.162.8.893

Young, T., Peppard, P.E., Taheri, S. (2005). Excess weight and sleep-disordered breathing. J. Appl. Physiol. 99, 1592-1599. https://doi.org/10.1152/japplphysiol.00587.2005

Yumino, D., Redolfi, S., Ruttanaumpawan, P., Su, M.C., Smith, S., Newton, G.E., Mak, S., Bradley, T.D. (2010). Nocturnal rostral fluid shift: A unifying concept for the pathogenesis of obstructive and central sleep apnea in men with heart failure. Circulation 121, 1598-1605. https://doi.org/10.1161/CIRCULATIONAHA.109.902452

Zanobetti, A., Redline, S., Schwartz, J., Rosen, D., Patel, S., O'Connor, G.T., Lebowitz, M., Coull, B.A., Gold, D.R. (2010). Associations of $\mathrm{PM}_{10}$ with sleep and sleep-disordered breathing in adults from seven U.S. Urban areas. Am. J. Respir. Crit. Care. Med. 182, 819-825. https://doi.org/10.1164/rccm.200912-17970C

Zhang, J.J., Li, N.F., Yao, X.G., Zhou, L., Shao, L., Hong, J., Yin, T., Kong, J.Q. (2014). Association of interleukin-1 $\beta$ genetic polymorphisms with obstructive sleep apnea syndrome. Zhongguo Yi Xue Ke Xue Yuan Xue Bao 36, 145-152. https://doi.org/10.3881/j.issn.1000-503X.2014.02.006

Zhao, R., Guo, Z., Zhang, R., Deng, C., Xu, J., Dong, W., Hong, Z., Yu, H., Situ, H., Liu, C., Zhuang, G. (2018). Nasal epithelial barrier disruption by particulate matter $\leq 2.5 \mu \mathrm{m}$ via tight junction protein degradation. J. Appl. Toxicol. 38, 678-687. https://doi.org/10.1002/jat.3573 